\title{
Physical characteristics and dynamics of the coastal Latex09 Eddy derived from in situ data and numerical modeling.
}

M. Kersalé, ${ }^{1}$ A. A. Petrenko, ${ }^{1}$ A. M. Doglioli, ${ }^{1}$ I. Dekeyser,${ }^{1}$ F. Nencioli ${ }^{1}$

${ }^{1}$ Aix-Marseille Université, Université du Sud Toulon-Var, CNRS/INSU, IRD, MIO, UM 110, 13288, Marseille, Cedex 09, France. 


\section{Abstract.}

${ }_{5}$ We investigate the dynamics of a coastal anticyclonic eddy in the west-

6 ern part of the Gulf of Lion (GoL) in the northwestern Mediterranean Sea

7 during the Latex campaign in the summer 2009 (Latex09). The sampling strat-

s egy combines SST satellite imagery, hull-mounted ADCP data, CTD casts

9 and drifter trajectories. Our measurements reveal an anticyclonic eddy ( $L a-$

10 tex09 eddy) with a diameter of $\sim 23 \mathrm{~km}$ and maximum depth of $31 \mathrm{~m}$, cen-

${ }_{11}$ tered at $3^{\circ} 34^{\prime} \mathrm{E}-42^{\circ} 33^{\prime} \mathrm{N}$. We use a high resolution, 3-dimensional, primi-

${ }_{12}$ tive equation numerical model to investigate its generation process and evo-

${ }_{13}$ lution. The model is able to reproduce the observed eddy, in particular its

${ }_{14}$ size and position. The model results suggest that the Latex09 eddy is induced

${ }_{15}$ by a large anticyclonic circulation in the northwestern part of the GoL, pushed

${ }_{16}$ and squeezed toward the coast by a meander of the Northern Current. This

17 represents a new generation mechanism that has not been reported before.

${ }_{18}$ The post generation dynamics of the eddy is also captured by the model. The

19 collision of the Latex09 eddy with Cape Creus results in a transient struc-

${ }_{20}$ ture, which is depicted by the trajectories of two Lagrangian drifters dur-

${ }_{21}$ ing Latex09. The transient structure and its advection lead to a transfer of

${ }_{22}$ mass and vorticity from the GoL to the Catalan shelf, indicating the impor-

${ }_{23}$ tance of mesoscale structures in modulating such exchanges in the region.

${ }_{24}$ Keywords: Coastal eddies, in situ measurements, numerical modeling, mesoscale, ${ }_{25}$ Gulf of Lion. 


\section{Introduction}

${ }_{26}$ Continental shelf processes are often affected by large eddies approaching the continental

${ }_{27}$ slope from the deep ocean. In several open-ocean studies these energetic features of the

${ }_{28}$ ocean circulation have been observed and described during their propagation onto the

${ }_{29}$ continental shelf [Lewis and Kirwan Jr., 1985; Kirwan Jr. et al., 1988; Vukovich and

so Waddel, 1991; Vidal et al., 1992; Richardson et al., 1994; Fratantoni et al., 1995; Hamilton

31 et al., 1999]. Studies that focus specifically on coastal eddies (the ones developed on the

32 continental shelf) are much scarcer.

33 Mitchelson-Jacob and Sundby [2001] have observed coastal eddies through the analysis

${ }_{34}$ of satellite images on the continental shelf of Norway. They found that the size of these

35 eddies depends on the width of the fjord, with a diameter between $20 \mathrm{~km}$ to $60 \mathrm{~km}$. An

36 anticyclonic eddy was sampled during a field campaign and followed by numerous drifters

${ }_{37}$ [Mitchelson-Jacob and Sundby, 2001; Saetre, 1999]. This anticyclonic eddy appeared to

${ }_{38}$ be a quasi-stationary feature [Eide, 1979], reaching $140 \mathrm{~m}$ depth. The wind direction, the

39 depth of the near-surface layer and the presence of stratification have been identified as

${ }_{40}$ strong factors influencing the characteristics of these eddies. The strong currents in this

${ }_{41}$ region have been linked directly to the formation of these eddies.

${ }_{42}$ Mesoscale anticyclonic eddies have been also investigated inside the Gulf of Alaska.

${ }_{43}$ These eddies are named according to the location of their generation: Sitka Eddies

${ }_{44}$ [Tabata, 1982], Haida Eddies [Crawford and Whitney, 1999] and Yakutat Eddies [Ladd

${ }_{45}$ et al., 2005]. They are baroclinic structures with a diameter of 150-300 km. These eddies

46 generally form in winter and detach from the continental margin in late winter and spring. 
${ }_{47}$ Haida Eddies usually form in the outflow of coastal waters [Crawford, 2002; Di Lorenzo

${ }_{48}$ et al., 2005]. Sitka and Yakutat Eddies are believed to form in flow instabilities along the

49 continental slope [Melson et al., 1999].

${ }_{50}$ Coastal cyclonic eddies have been also investigated further south along the British ${ }_{51}$ Columbia shelf. The presence of a quasi-stationary eddy, the Juan de Fuca Eddy, on ${ }_{52}$ the southern Vancouver Island shelf has been described in several studies [Tully, 1942;

${ }_{53}$ Freeland and Denman, 1982; Denman and Freeland, 1985; Freeland and McIntosh, 1989;

${ }_{54}$ MacFadyen et al., 2008]. This eddy is a topographically confined eddy which develops off

${ }_{55}$ Cape Flattery in spring with a diameter of $80 \mathrm{~km}$ below $100 \mathrm{~m}$ depth.

${ }_{56}$ Current separation from capes has been proposed as an explanation for eddy formation ${ }_{57}$ in many coastal flows behind capes or headlands [Signell and Geyer, 1991; Doglioli et al., ${ }_{58}$ 2004; Magaldi et al., 2010]. However, in the case of the buoyant flow around Cape Flattery, ${ }_{59}$ the Coriolis force does not tend to maintain the current close to the coast [MacFadyen and ${ }_{60}$ Hickey, 2010]. In fact, the eddy generation has been linked to two upwelling processes ${ }_{61}$ occurring in the area with the important contribution of tidal forcing in the initial eddy ${ }_{62}$ generation process [Foreman et al., 2008; MacFadyen and Hickey, 2010].

${ }_{63}$ In general, the dynamics and the role of mesoscale coastal eddies are very complex ${ }_{64}$ and different from one region to another. These eddies can translate away from their ${ }_{65}$ generation region with the mean flow [Crawford et al., 2007; Mitchelson-Jacob and Sundby, ${ }_{6}$ 2001] or they can be quasi-stationary and linked to the topography [Eide, 1979; Freeland ${ }_{67}$ and Denman, 1982]. Other studies highlight the role of mesoscale eddies on coastal ${ }_{68}$ upwelling processes in idealized ecosystems [Lathuilière et al., 2010] or in the Ligurian Sea

${ }_{69}^{[}[$Casella et al., 2011]. In either case, they have profound impacts on local mechanisms 
70 of water transport, vertical mixing and circulation processes. They are often biologically

${ }_{71}$ rich regions because they can transport nutrient-rich coastal water off the coast to open

72 ocean.

${ }_{73}$ The Gulf of Lion (GoL) is particularly relevant for the study of coastal mesoscale struc-

74 tures. The GoL is located in the northwestern Mediterranean Sea and is characterized by

75 a large continental margin (Figure 1). Its hydrodynamics is complex and highly variable

${ }_{76}[$ Millot, 1990$]$. The circulation is strongly influenced by the Northern Current (NC), which

77 constitutes an effective dynamical barrier blocking coastal waters on the continental shelf

78 [Albérola et al., 1995; Sammari et al., 1995; Petrenko, 2003]. Exchanges between the GoL

79 and offshore waters are mainly induced by processes associated with the $\mathrm{NC}$ [Conan and

so Millot, 1995; Flexas et al., 2002; Petrenko et al., 2005].

${ }_{81}$ In the eastern part of the GoL, south of Marseilles, Allou et al. [2010] have observed the 82 presence of anticyclonic eddies between the $\mathrm{NC}$ and the coast using current meter data and 8з surface currents measured by High Frequency (HF) radars. The eddies are of diameters

${ }_{84} 12$ to $28 \mathrm{~km}$ and they are coherent down to a depth of $140 \mathrm{~m}$. Baroclinic instability of the

${ }_{85} \mathrm{NC}$ is a possible generation mechanism [Flexas et al., 2002]. Schaeffer et al. [2011] have

${ }_{86}$ also observed anticyclonic eddies, with a diameter of $20-40 \mathrm{~km}$, in the eastern part of the

${ }_{87}$ GoL with HF radars and numerical simulations. They have shown that their generation

s8 mechanism is related to the local wind conditions. After their generation, some of the

${ }_{89}$ eddies are advected by the NC towards the western part of the shelf.

${ }_{90}$ The instability of the NC and its role on the advection of eddies has been also proposed ${ }_{91}$ to explain the presence of anticyclonic eddies on the Catalan continental shelf [ Rubio et al., ${ }_{92}$ 2005]. However Rubio et al. [2009a] rejected their previous hypothesis and suggested that 
${ }_{93}$ the process of flow separation due to a topographic barrier generates these eddies. A

${ }_{94}$ possible mechanism for the generation of the Catalan eddies is described by Garreau ${ }_{95}$ et al. [2011] in terms of release of potential energy from other eddies located in the GoL.

${ }_{96}$ Through ADCP measurements and numerical simulations Estournel et al. [2003] showed ${ }_{97}$ a large anticyclonic circulation located in the northwestern part of the GoL. In this part ${ }_{98}$ of the GoL, a mesoscale anticyclonic circulation was first described by Millot [1979, 1982].

99 Hu et al. [2009, 2011a] showed the presence of a mesoscale eddy by a combined use of 100 data from satellite observations, in situ measurements and numerical modeling. The 101 eddies were baroclinic structures extending throughout the mixed layer (30 to $50 \mathrm{~m}$ ), 102 often elliptical in shape and about $20-30 \mathrm{~km}$ in diameter (elliptical diameter is defined as ${ }_{103}$ the mean of the minor and major axes). The generation process of the eddies mentioned 104 by $H u$ et al. [2009, 2011a] required two conditions: a persistent and strong northwest wind 105 and a strong stratification [Hu et al., 2011b].

The LAgrangian Transport EXperiment (LATEX) project (2008-2011) is designed to exchanges in the western part of the GoL. The dynamics of mesoscale eddies is particularly important in this part of the GoL since it represents a key region for regulating the outflow ${ }_{110}$ from the continental shelf [Hu et al., 2011a; Nencioli et al., 2011].

The aim of the present study is to analyze the dynamical characteristics and generation 112 processes of such eddies during the summer of 2009. The methods used are described in ${ }_{113}$ Section 2. Results based on a combination of satellite and in situ oceanographic data, ${ }_{114}$ as well as numerical results are presented in Section 3. The general characteristics of the 
115 observed eddies, their possible generation mechanisms and their behaviors are discussed 116 in Section 4.

\section{Methods}

The LATEX strategy was based on a combined use of Eulerian and Lagrangian in situ measurements, satellite data and numerical modeling. The Latex09 campaign, conducted ${ }_{119}$ from August 24 to 28, 2009 on board the R/V Téthys II, was the second field experiment of the LATEX project.

\subsection{Data}

Identifying the center of an eddy is one of the greatest challenges in the eddy commu- 
135 in near real-time during the entire campaign using the method described by Nencioli

136 et al. [2008]. A searching grid of $30 \times 30$ points corresponding to a $30 \times 30 \mathrm{~km}$ square area

${ }_{137}$ was imposed within each transect. Each grid point was tested as a possible location,

${ }_{138}$ at that depth, for the center of the eddy. For each grid point, the components of the

139 ADCP velocities from a transect were decomposed into radial and tangential components

${ }_{140}$ with respect to the reference frame centered at each point. The center, hereafter referred

${ }_{141}$ to as single-depth transect center, was estimated as the grid point for which the mean

${ }_{142}$ tangential velocity computed from the nearest ADCP records (black vectors - Figure 2)

${ }_{143}$ was maximum.

In the present paper, the analysis focuses on Transect 1 and three other transects that cross its center (Figure 2). Transect 2 is orthogonal to the coast (Figure 2b), Transect 3

146 is orthogonal to the continental slope (Figure 2c) and Transect 4 follows it (Figure 2d).

${ }_{147}$ The start and end times for each transect are reported in Table 1.

During the transect mapping, we also collected a total of 25 profiles at specific locations using a SeaBird SBE 19 CTD. We only show three of the CTD profiles, one inside the ${ }_{150}$ eddy (CTD_in, blue cross - Figure 5a), one at the edge (CTD_edge, red cross) and one ${ }_{151}$ outside the eddy (CTD_out, black cross), representing eddy center, eddy edge and outside conditions, respectively. Two satellite-tracked drifters, anchored at $15 \mathrm{~m}$ depth, were deployed within the eddy to track the fluid motion. Drifter positions were provided by the Argos system in quasi-real time. In addition, sea surface temperature, salinity and fluorescence were measured continuously at the surface by the ship's thermosalinometer SBE 21. 


\subsection{Ocean model}

In addition to the in situ measurements, the eddy dynamics have been investigated using Symphonie, a 3-dimensional, primitive equation model, with a free sea surface, hybrid sigma coordinates, based on Boussinesq and hydrostatic approximations [Marsaleix et al., 2006, 2008]. We use the upwind-type advection-diffusion scheme adapted by $\mathrm{Hu}$ et al. [2009] to improve the ability of the model to reproduce coastal mesoscale eddies in the western part of the GoL. In the present study, the model is implemented over the whole GoL with an horizontal resolution of $1 \mathrm{~km} \times 1 \mathrm{~km}$ (Figure 1). The vertical discretization consists of 40-hybrid vertical levels. The vertical resolution varies from $1 \mathrm{~m}$ in the upper ocean to $40 \mathrm{~m}$ near the bottom.

This high resolution model is one-way nested to a coarse grid model $(3 \mathrm{~km} \times 3 \mathrm{~km})$ covering a larger domain. The initial and open boundary conditions for the larger domain are provided by the Mediterranean Forecasting System (MFS) general circulation model [Pinardi, 2003] with a resolution of $1 / 8^{\circ}$. The atmospheric forcing is obtained from the 3-hr outputs of the meteorological model Aladin of Météo-France with a spatial resolution of $0.1^{\circ} \times 0.1^{\circ}$. The daily fresh water fluxes from the major rivers are taken into account. The readers are referred to $H u$ et al. [2011b] for more details about the model settings.

This model was run from 2001 to 2008 and the results were analyzed by $H u$ et al. [2011b]. In the present study it is run for 2009, with a restart from the previous simulation.

The daily outputs of current velocity components, salinity, temperature and density are averaged over 24 hours of simulation, to filter out the diurnal cycle. We have verified that the 24-hours average is also effective in filtering out the inertial oscillations, that is of 
X - 10 KERSALE ET AL.: STUDY OF THE LATEX09 EDDY - IN SITU \& NUMERICAL DATA

$178 \sim 17.5$ hours in the GoL. The remaining unfiltered inertial kinetic energy represents 1-5\%

179 of the total average kinetic energy. 
${ }_{201}$ center of the modeled eddy is defined as the maximum in magnitude of relative vorticity.

${ }_{202}$ For each eddy, tracking can be performed both backward and forward in time to find the

${ }_{203}$ "birth" and the "death" of the eddy. At each time step, the eddy's diameter, D, is defined

204 as the average between the zonal $\left(D^{E W}\right)$ and the meridional $\left(D^{N S}\right)$ cords that intercept

205 each eddy center with both endpoints on the edge of the structure. This definition accounts for stretched shapes. The analysis is repeated at each depth level $(\mathrm{k})$ to diagnose

In the following, our results are written as $D \pm \sqrt{D_{v a r}}$.

\section{Results}

\subsection{In situ experiment}


KERSALE ET AL.: STUDY OF THE LATEX09 EDDY - IN SITU \& NUMERICAL DATA X - 13 
X - 14 KERSALE ET AL.: STUDY OF THE LATEX09 EDDY - IN SITU \& NUMERICAL DATA

${ }_{267}$ and are within the studied eddy. The resulting estimations of the diameter and the

${ }_{268}$ position of the single-depth transect centers are summarized in Table 2 . In the table we

${ }_{269}$ introduce two other center estimates. The depth-averaged transect centers are defined

${ }_{270}$ as the mean of the positions of the single-depth transect centers. The transect-averaged

${ }_{271}$ eddy center, hereafter named for simplification eddy center $\mathbf{C}$, is defined as the mean of

${ }_{272}$ the positions of the depth-averaged transect centers. The estimated position of the eddy

${ }_{273}$ center corresponds to the depth-averaged transect center for Transect 1 (C1-Table 2).

274 Transects 3 and 4 are approximately meridional and zonal, respectively, and thus they

${ }_{275}$ are also roughly perpendicular (Figure 2). Therefore, in order to estimate the diameter

${ }_{276}$ from in situ data, we apply eq(1) where $D_{E W}\left(D_{N S}\right)$ is the distance between the two

${ }_{277}$ maximum values of tangential velocities on Transect 3 (4) at the three reference depths

${ }_{278}(11 \mathrm{~m}, 15 \mathrm{~m}, 19 \mathrm{~m})$. The diameter of the eddy is thereby estimated to be $22.7 \pm 1.2 \mathrm{~km}$.

279 Another way to evaluate the vertical extension of the eddy comes from the analysis of the

${ }_{280}$ vertical profiles of temperature and fluorescence (Figure 5). The temperature profiles show

${ }_{281}$ values between $23.0^{\circ} \mathrm{C}$ and $23.6^{\circ} \mathrm{C}$ at the surface and a progressive decrease with depth

${ }_{282}$ to a value of $13.4^{\circ} \mathrm{C}$ at about $150 \mathrm{~m}$ depth (Figure 5b). A strong thermocline is observed

${ }_{283}$ between 8 and $18 \mathrm{~m}$ (20 and $35 \mathrm{~m}$ ), at station CTD_out (CTD_in), outside (inside) the

${ }_{284}$ eddy. Indeed the anticyclonic eddy corresponds to a deepening of the thermocline. We

${ }_{285}$ also notice a weak value of fluorescence at the surface for all three profiles (Figure 5c). A

${ }_{286}$ fluorescence peak reaching $2.5 \mu \mathrm{g} \mathrm{l}^{-1}$ is visible at $50 \mathrm{~m}$ depth outside the eddy (station

${ }_{287}$ CTD_out); it decreases to less than $2 \mu \mathrm{g} \mathrm{l} \mathrm{l}^{-1}$ at the edge of the eddy (station CTD_edge).

${ }_{288}$ Only a faint maximum of $0.6 \mu \mathrm{g} \mathrm{l}^{-1}$ can be found at $70 \mathrm{~m}$ depth inside the eddy (station 
KERSALE ET AL.: STUDY OF THE LATEX09 EDDY - IN SITU \& NUMERICAL DATA X - 15

${ }_{289}$ CTD_in), deeper than the thermocline. This agrees with a reduced phytoplankton biomass

290 induced by the downwelling associated with anticyclonic eddies [Siegel et al., 2011].

\subsection{Modeling results}

The study of the numerical model outputs with the wavelet analysis allows us to retrieve

information about the various mesoscale structures in the study area in 2009. Hereafter,

${ }_{293}$ we adopt the terminology introduced by Hu et al. [2011b] who defined "long-life" eddies

${ }_{294}$ as the ones which last for at least 15 days. We have thoroughly studied year 2009 and two modeled "long-life" anticyclonic eddies are identified. The wavelet analysis shows that the first "long-life" eddy (hereafter A1) is generated on June 28 and lasts until July 20, while the second eddy is generated on August 16 and lasts until October 12. The latter is considered to be analogous to the eddy sampled during Latex09 and described in Section 3.1, and hence is hereafter referred to as A2-Latex09.

First, we want to understand the generation mechanism of these two eddies. The generation process of eddy $A 1$ starts with a strong northwesterly wind observed from June 19 to 21. This strong wind, with an amplitude equal to $18 \mathrm{~m} \mathrm{~s}^{-1}$, induces an Ekman transport piling the water close to Cape Creus. Then a northward current along the 304 Roussillon coast starts on June 26. The closing of this Ekman southwestward drift and coastal current jet generates the anticyclonic eddy. An intermediate stratification has also 
${ }_{311}$ anticyclonic circulation extending to all the western GoL on July 20 (Figure 6e). In 312 the western part of the GoL, the positive sea surface height (Figure 6f) corresponds ${ }_{313}$ to an anticyclonic circulation extending south of Cape Creus. A meander of the NC 314 approaches this large anticyclonic circulation, squeezing it and reinforcing the current at 315 its southeastern edge. This occurs during a northwesterly wind event (Figure 6b) that 316 started on August 6. It produces a localized upwelling south of Cape d'Agde but smaller 317 than the one observed in the generation process proposed by Hu et al. [2011b]. During 318 this generation process, the wind can be classified on August 27 as a strong northwesterly 319 wind event $\left(16 \mathrm{~m} \mathrm{~s}^{-1}\right)$ but not persistent since its occurrence during the last three days ${ }_{320}$ is less than $75 \%$. A strong stratification has also been identified with an absolute value ${ }_{321}$ of potential energy anomaly more than $100 \mathrm{~J} \mathrm{~m}^{-3}$. On August 16 the wavelet analysis 322 identifies two anticyclonic eddies corresponding to the zonal separation of the anticyclonic ${ }_{323}$ area in two smaller areas (Figure 6g). Indeed the NC meander seems to push and squeeze ${ }_{324}$ the structure to the west. Then, as the presence of the coast blocks its progression, the ${ }_{325}$ structure becomes separated in two structures: one eddy on the shelf of the GoL (A2326 Latex09) and one moving inside the Catalan Basin. On August 27, these structures are ${ }_{327}$ clearly distinct (Figure 6h). In the following, the eddy in the Catalan shelf is referred to ${ }_{328}$ as the Catalan Eddy.

In the next paragraphs, the characteristics of A2-Latex09 on August 27 are presented 330 for comparison with the in-situ data sampled at the same time (Table 1). The modeled 331 A2-Latex09 extends throughout the mixed layer until $37 \mathrm{~m}$ depth. The wavelet analysis ${ }_{332}$ identifies an eddy centered at $3^{\circ} 26^{\prime} \mathrm{E}-42^{\circ} 36^{\prime} \mathrm{N}$ with a diameter of $28.6 \pm 1.4 \mathrm{~km}$. The 33з position of the eddy's center is calculated as the mean of its positions between 1 and $37 \mathrm{~m}$ 
KERSALE ET AL.: STUDY OF THE LATEX09 EDDY - IN SITU \& NUMERICAL DATA X - 17 
X - 18 KERSALE ET AL.: STUDY OF THE LATEX09 EDDY - IN SITU \& NUMERICAL DATA

${ }_{357}$ rotation period of this buoy to ascertain the nature of this feature, we found a rotation pe-

358 riod of 39 hours, corresponding approximately to half the rotation period of A2-Latex09.

359 This rotation does not correspond to an inertial oscillation, which has a typical period of

$360 \sim 17.5$ hours in the GoL. This fact confirms the hypothesis that the drifter is trapped in

361 the transient structure. On September 6, Drifter No. 83632 got trapped in the Catalan

${ }_{362} E d d y$ located at $3^{\circ} 11^{\prime} \mathrm{E}-41^{\circ} 35^{\prime} \mathrm{N}$.

\section{Discussion and Concluding remarks}

The generation and characteristics of a coastal anticyclonic eddy detected in the western part of the GoL have been studied from a combination of in situ measurements and numerical modeling from the end of August 2009 to the middle of October 2009.

On the basis of in situ measurements, the anticyclonic eddy is centered at $3^{\circ} 34^{\prime} \mathrm{E}-$ $42^{\circ} 33^{\prime} \mathrm{N}$ and is characterized by a diameter of $22.7 \pm 1.2 \mathrm{~km}$, reaching a maximal depth of $31 \mathrm{~m}$. The observed anticyclonic eddy is well reproduced by the model as shown by the numerical relative vorticity field on September 3 (Figure 8a). The major characteristics of this modeled eddy agree with the observations, although its horizontal dimensions are

$\left.{ }_{375} \frac{V_{\max }}{R_{\max } f}\right)$ and the the Rossby radius of deformation $\left(\mathrm{R}_{d}=\frac{\sqrt{g^{\prime} H^{\prime}}}{f}\right) . V_{\max }$ is calculated as the 
KERSALE ET AL.: STUDY OF THE LATEX09 EDDY - IN SITU \& NUMERICAL DATA X - 19

${ }_{379}$ the eddy is 0.26 . To compute $\mathrm{R}_{d}$, the reduced gravity was calculated as $g^{\prime}=\frac{\rho_{2}-\rho_{1}}{\rho_{2}} g$, with ${ }_{380} \rho_{2}=1029.04 \mathrm{~kg} \mathrm{~m}^{-3}$, the mean density below the mixed layer, and $\rho_{1}=1025.75 \mathrm{~kg} \mathrm{~m}^{-3}$, ${ }_{381}$ the mean density within the mixed layer. The mixed layer depth was $10.9 \mathrm{~m}$. The resulting ${ }_{382} \mathrm{R}_{d}$ is $5.9 \mathrm{~km}$, which is smaller than the eddy reference radius $\mathrm{R}_{\max }$. Since $\mathrm{R}_{\max }>\mathrm{R}_{d}$, we ${ }_{383}$ can objectively classify the eddy as a mesoscale structure. Since the local Rossby number 384 is not small, its dynamics can not be approximated by quasi-geostrophic theory.

We can compare our results with the data gathered during the experiment Latex08 in 386 the same area [Hu et al., 2011a] conducted from September 1 to 5, 2008. Although the ${ }_{387}$ generation process is different, these two coastal anticyclonic eddies have similar characteristics in terms of position, extension and dynamical characteristics. This fact shows

звя the important influence of coast and bathymetry on the physical characteristics of these 390 mesoscale eddies.

${ }_{391}$ Hu et al. [2011a] emphasized that the 2008 eddy interacts with the Northern Current 392 at the end of the Latex08 campaign, leading to its deformation and maybe to its death. ${ }_{393}$ In our case, the presence and role of the Northern Current is much clearer (Figures 2b,c). ${ }_{394}$ The NC has first created the eddy and then it affected it, reinforcing the current at its 395 southeastern part. This intensification could explain the asymmetric shape of the eddy. Regarding the possible mechanisms for the formation of these anticyclonic eddies in the 
X - 20 KERSALE ET AL.: STUDY OF THE LATEX09 EDDY - IN SITU \& NUMERICAL DATA

402 responds to $\mathrm{Hu}$ et al. [2011b]'s process with the two conditions described above. A strong

${ }_{403}$ northwesterly wind is observed from June 19 to 21 and an intermediate stratification is

404 noted at the end of June with an absolute value of potential energy anomaly greater than

${ }_{405} 60 \mathrm{~J} \mathrm{~m}^{-3}$.

${ }_{406}$ Instead, for anticyclonic eddy A2-Latex09, we propose a new process of generation, associated with the NC. This new mechanism starts with the generation of an anticyclonic

${ }_{408}$ circulation extending over a large part of the coastal area (Figure 6e). The generation of

${ }_{409}$ this anticyclonic circulation, precursor to the eddy, is not analyzed in this study but it ${ }_{410}$ could have been generated by the mechanism proposed by $H u$ et al. [2011b]. Interaction ${ }_{411}$ with a meander of the Northern Current and the presence of the coast induces the latitu${ }_{412}$ dinal separation of this anticyclonic circulation into two eddies, the northern one in the ${ }_{413}$ GoL and the southern one on the Catalan shelf. To our knowledge, this generation process ${ }_{414}$ has not been proposed before. Indeed the combined analysis of Rubio et al. [2005, 2009a] ${ }_{415}$ suggests that Catalan eddies are generated downstream of Cape Creus as a result of a ${ }_{416}$ flow separation triggered by an intense northwest wind event in the GoL. While Garreau ${ }_{417}$ et al. [2011] indicate that GoL eddies flow southward creating Catalan eddies after a burst ${ }_{418}$ of southeasterlies and northerlies. The authors conclude that the death of GoL eddies is ${ }_{419}$ clearly linked to the birth of strong Catalan eddies. In our case, the detachment of a part ${ }_{420}$ of the eddy does not lead to the death of A2-Latex09. The formation of this transient ${ }^{421}$ structure comes from the encounter of the A2-Latex09 with Cape Creus. The generation ${ }_{422}$ of this transient structure causes a loss of mass and vorticity for A2-Latex09. In the in-situ measurements, a small structure is detected in the same spatial area and at the same time ${ }_{424}$ (Figure 8b) as the one given by the model (Figure 8a). When drifter No. 83632 starts 
KERSALE ET AL.: STUDY OF THE LATEX09 EDDY - IN SITU \& NUMERICAL DATA X - 21 ${ }_{425}$ to loop outside the eddy (Figure 8b), drifting toward the south, its rotation period (39 ${ }^{426}$ hours) eliminates the occurrence of an inertial oscillation. After $\sim 6$ days this drifter is ${ }_{427}$ caught by the Catalan Eddy located at $3^{\circ} 11^{\prime} \mathrm{E}-41^{\circ} 35^{\prime} \mathrm{N}$. The generation of the transient ${ }_{428}$ structure moving from A2-Latex09 toward the Catalan Eddy in the model results can ${ }_{429}$ explain the trajectories of these drifters. From the $i n$-situ experiment it is clear that the ${ }_{430}$ generation of this structure leads directly to a transfer of mass from the eddy of the GoL 431 to the eddy of the Catalan shelf.

${ }_{432}$ This study gives a more complete and consistent picture of the GoL coastal eddy dy${ }_{433}$ namics. A full 3D analysis from numerical simulation will be made with the objective ${ }_{434}$ of better understanding the remaining open questions about the generation of the an${ }_{435}$ ticyclonic circulation, first step of the proposed new generation process. Besides, this ${ }_{436}$ numerical modeling work would be useful to explore the coupled physical and biogeo${ }_{437}$ chemical dynamics at mesoscale and the role of mesoscale eddies in the transfers between ${ }_{438}$ the GoL coastal zone and the neighboring coastal regions.

${ }_{439}$ Acknowledgments. The LATEX project is supported by the programs LEFE/IDAO ${ }_{440}$ and LEFE/CYBER of the INSU-Institut National des Sciences de l'Univers and by the ${ }_{441}$ Region PACA-Provence Alpes Côte d'Azur. The meteorological data were kindly supplied ${ }_{442}$ by Météo-France. We acknowledge the MFS program for OGCM outputs. We are warmly ${ }_{443}$ grateful to the crews of the $\mathrm{R} / \mathrm{V}$ Téthys II for their assistance. We thank $\mathrm{Z}$. Y. Hu for ${ }_{444}$ providing the last configuration of the model. The authors want to thank J. Bouffard and ${ }_{445}$ C. Yohia for precious comments and useful discussions. Marion Kersalé is financed by a ${ }_{446}$ MENRT Ph.D. grant. 


\section{References}

${ }_{447}$ Albérola, C., C. Millot, and J. Font (1995), On the seasonal and mesoscale variabilities of

${ }_{448}$ the Northern Current during the PRIMO-0 experiment in the western Mediterranean Sea, Oceanol. Acta, 18(2), 163-192.

Allou, A., P. Forget, and J. L. Devenon (2010), Submesoscale vortex strucures at the entrance of the Gulf of Lions in the Northwestern Mediterranean Sea, Cont. Shelf Res., 30, 724-732, doi:10.1016/j.csr.2010.01.006.

Burchard, H., and R. Burchard (2008), A dynamic equation for the potential energy anomaly for analysing mixing and stratification in estuaries and coastal seas, Estuarine, Coastal Shelf Science, $77(4), 679-687$, doi:10.1016/j.ecss.2007.10.025.

Casella, E., A. Molcard, and A. Provenzale (2011), Mesoscale vortices in the Ligurian Sea and their effect on coastal upwelling processes, J. Mar. Sys., 88(1), 12-19, doi: 10.1016/j.jmarsys.2011.02.019.

Conan, P., and C. Millot (1995), Variability of the Northern Current off Marseilles, western Mediterranean Sea, from February to June 1992, Oceanol. Acta, 18(2), 193-205.

Crawford, W. R. (2002), Physical characteristics of Haida Eddies, Journal of Oceanography, 58(5), 703-713, doi:10.1023/A:1022898424333.

Crawford, W. R., and F. A. Whitney (1999), Mesoscale eddy aswirl with data in Gulf of Alaska Ocean, Eos, Trans. AGU, 80(33), 365-670.

Crawford, W. R., P. J. Brickley, and A. C. Thomas (2007), Mesoscale eddies dominate surface phytoplankton in northern Gulf of Alaska, Prog. Oceanogr., 75, 287-303, doi: 10.1016/j.pocean.2007.08.016. 
KERSALE ET AL.: STUDY OF THE LATEX09 EDDY - IN SITU \& NUMERICAL DATA X - 23

${ }_{468}$ De Boer, G. J., J. D. Pietrzak, and J. C. Winterwerp (2008), Using the potential energy anomaly equation to investigate tidal straining and advection of stratification in a region of freshwater influence, Ocean Model., 22, 1-11.

Dencausse, G. J., M. Arhan, and S. Speich (2010), Routes of agulhas rings in the south eastern cape basin, Deep-Sea Res. I, 57, 1406-1421, doi:10.1016/j.dsr.2010.07.008.

Denman, K. L., and H. J. Freeland (1985), Correlation scales, objective mapping and a statistical test of geostrophy over the continental shelf, J. Mar. Res., 43(3), 517-539, doi:10.1357/002224085788440402.

Di Lorenzo, E., M. G. G. Foreman, and W. R. Crawford (2005), Modelling the generation of Haida Eddies, Deep-Sea Res. II, 52, 853-873, doi:10.1016/j.dsr2.2005.02.007.

Doglioli, A. M., A. Griffa, and M. G. Magaldi (2004), Numerical study of a coastal current on a steep slope in presence of a cape: The case of the Promontorio di Portofino, J. Geophys. Res., 109, C12033, doi:10.1029/2004JC002422.

Doglioli, A. M., B. Blanke, S. Speich, and G. Lapeyre (2007), Tracking coherent structures in a regional ocean model with wavelet analysis: application to Cape Basin Eddies, J. Geophys. Res., 112, C05043, doi:10.1029/2006JC003952.

Eide, L. I. (1979), Evidence of a topographically trapped vortex on the Norwegian continental shelf, Deep-Sea Res. I, 26 (6), 601-621, doi:10.1016/0198-0149(79)90036-0.

Estournel, C., X. Durrieu de Madron, P. Marsaleix, F. Auclair, C. Julliand, and R. Vehil (2003), Observation and modeling of the winter coastal oceanic circulation in the Gulf of Lion under wind conditions influenced by the continental orography (FETCH experiment), J. Geophys. Res., 108(C3), 8059, doi:10.1029/2001JC000825. 
X - 24 KERSAlE ET AL.: STUDY OF THE LATEX09 EDDY - IN SITU \& NUMERICAL DATA

${ }_{490}$ Flexas, M. M., X. Durrieu de Madron, M. A. Garcia, M. Canals, and P. Arnau (2002), 
KERSALE ET AL.: STUDY OF THE LATEX09 EDDY - IN SITU \& NUMERICAL DATA X -25

10.1016/j.jmarsys.2011.02.008.

Hu, Z. Y., A. A. Petrenko, A. M. Doglioli, and I. Dekeyser (2011b), Numerical study of eddy generation in the western part of the Gulf of Lion, J. Geophys. Res., 116, C12030, doi:10.1029/2011JC007074.

Kirwan Jr., A. D., J. K. Lewis, A. W. Indest, P. Reinersman, and I. Quintero (1988), Observed and Simulated Kinematic Properties of Loop Current Rings, J. Geophys. Res., 93(C2), 1189-1198, doi:10.1029/JC093iC02p01189.

Ladd, C. M., N. B. Kachel, C. W. Mordy, and P. J. Stabeno (2005), Observations from a Yakutat eddy in the northern Gulf of Alaska, J. Geophys. Res., 110(C03003), doi: 10.1029/2004JC002710.

Lathuilière, C., V. Echevin, M. Lévy, and G. Madec (2010), On the role of the mesoscale circulation on an idealized coastal upwelling ecosystem, J. Geophys. Res., 115, C09018, doi:10.1029/2009JC005827.

Lewis, J. K., and A. D. Kirwan Jr. (1985), Some observations of ring topography and ring-ring interactions in the Gulf of Mexico, J. Geophys. Res., 90(C5), 9017-9028, doi: 10.1029/JC090iC05p09017.

MacFadyen, A., and B. M. Hickey (2010), Generation and evolution of a topographically linked, mesoscale eddy under steady and variable wind-forcing, Cont. Shelf Res., 30(13), 1387-1402, doi:10.1016/j.csr.2010.04.001.

MacFadyen, A., B. M. Hickey, and W. P. Cochlan (2008), Influences of the Juan de Fuca Eddy on circulation, nutrients, and phytoplankton production in the northern California Current System, J. Geophys. Res., 113(C08008), doi:10.1029/2007JC004412. 
X - 26 KERSALE ET AL.: STUDY OF THE LATEX09 EDDY - IN SITU \& NUMERICAL DATA

${ }_{535}$ Magaldi, M., T. Özgökmen, A. Griffa, and M. Rixen (2010), On the response of a turbulent

coastal buoyant current to wind events: the case of the Western Adriatic Current, Ocean Dynam., 60, 93-122, doi:10.1007/s10236-009-0247-9.

Marsaleix, P., F. Auclair, and C. Estournel (2006), Considerations on Open Boundary Conditions for Regional and Coastal Ocean Models, J. Atmos. Ocean. Technol., 23, 1604-1613, doi:10.1175/JTECH1930.1.

Marsaleix, P., F. Auclair, J. Floor, M. Herrmann, C. Estournel, I. Pairaud, and C. Ulses (2008), Energy conservation issues in sigma-coordinate free-surface ocean models, Ocean Model., 20, 61-89, doi:10.1016/j.ocemod.2007.07.005.

Melson, A., S. D. Meyers, H. E. Hurlburt, E. J. Metzger, and J. J. O'Brien (1999), ENSO effects on Gulf of Alaska eddies, Earth Interactions 3, 003, doi:10.1175/1087-3562.

Millot, C. (1979), Wind induced upwellings in the Gulf of Lions, Oceanol. Acta, 2, 261274.

Millot, C. (1982), Analysis of upwelling in the Gulf of Lions - Hydrodynamics of semienclosed seas: Proceedings of the 13th International Liège Colloquium on Ocean Hydrodynamics., vol. 34, 143-153 pp., Elsevier Oceanogr. Ser., Amsterdam, The Netherlands. Millot, C. (1990), The Gulf of Lions' hydrodynamics, Cont. Shelf Res., 10, 885-894, doi: 10.1016/0278-4343(90)90065-T.

Mitchelson-Jacob, G., and S. Sundby (2001), Eddies of Vestfjorden, Norway, Cont. Shelf Res., 21(16-17), 1901-1918, doi:10.1016/S0278-4343(01)00030-9.

Nencioli, F., V. S. Kuwahara, T. D. Dickey, Y. M. Rii, and R. R. Bidigare (2008), Physical dynamics and biological implications of a mesoscale eddy in the lee of Hawai'i : Cyclone Opal observations during E-FLUX III, Deep-Sea Res. II, 55(10-13), 1252-1274, doi: 
KERSALE ET AL.: STUDY OF THE LATEX09 EDDY - IN SITU \& NUMERICAL DATA X X - 27 10.1016/j.dsr2.2008.02.003.

Nencioli, F., F. d'Ovidio, A. M. Doglioli, and A. A. Petrenko (2011), Surface coastal circulation patterns by in-situ detection of Lagrangian coherent structures, Geophys. Res. Lett., 38(L17604), doi:10.1029/2011GL048815.

Petrenko, A. A. (2003), Variability of circulation features in the Gulf of Lion NW Mediterranean Sea. Importance of inertial currents, Oceanol. Acta, 26, 323-338.

Petrenko, A. A., Y. Leredde, and P. Marsaleix (2005), Circulation in a stratified and wind-forced Gulf of Lions, NW Mediterranean Sea: in situ and modeling data, Cont. Shelf Res., 25, 7-27, doi:10.1016/j.csr.2004.09.004.

Pinardi, N. (2003), The Mediterranean ocean forcasting system : first phase of implementation (1998-2001), Ann. Geophys., 21, 3-20, doi:10.5194/angeo-21-3-2003.

Richardson, P. L., G. E. Hufford, and R. I. Limeburner (1994), North Brazil Current retroflection eddies, J. Geophys. Res., 99(C3), 5081-5093, doi:doi:10.1029/93JC03486.

Rubio, A., P. Arnau, M. Espino, M. Flexas, G. Jordà, J. Salat, J. Puigdefàbregas, and A. S.-Arcilla (2005), A field study of the behaviour of an anticyclonic eddy on the Catalan continental shelf (NW Mediterranean), Prog. Oceanogr., 66(2-4), 142-156, doi: 10.1016/j.pocean.2004.07.012.

Rubio, A., B. Barnier, G. Jordà, M. Espino, and P. Marsaleix (2009a), Origin and dynamics of mesoscale eddies int he Catalan Sea (NW Mediterranean): Insight from a numerical model study, J. Geophys. Res., 114(C06009), 1-17, doi:10.1029/2007JC004245.

Rubio, A., B. Blanke, S. Speich, N. Grima, and C. Roy (2009b), Mesoscale eddy activity in the southern Benguela upwelling system from satellite altimetry and model data, Prog. Oceanogr., 83(1-4), 288-295, doi:10.1016/j.pocean.2009.07.029. 
X - 28 KERSALE ET AL.: STUDY OF THE LATEX09 EDDY - IN SITU \& NUMERICAL DATA

${ }_{581}$ Saetre, R. (1999), Features of the central Norwegian shelf, Cont. Shelf Res., 19(14), 18091831, doi:10.1016/S0278-4343(99)00041-2.

Sammari, C., C. Millot, and L. Prieur (1995), Aspects of the seasonal and mesoscale variabilities of the Northern Current inferred from the PROLIG-2 and PROS-6 experiments, Deep-Sea Res. I, 42(6), 893-917, doi:10.1016/0967-0637(95)00031-Z.

Schaeffer, A., A. Molcard, P. Forget, P. Fraunié, and P. Garreau (2011), Generation mechanisms for mesoscale eddies in the Gulf of Lions : radar observation and modeling, Ocean Dynam., 61, 1587-1609, doi:10.1007/s10236-011-0482-8.

Siegel, D. A., P. Peterson, D. J. McGillicuddy, S. Maritorena, and N. B. Nelson (2011), Biooptical footprints created by mesoscale eddies in the Sargasso Sea, Geophys. Res. Lett., 38 (L13608), doi:doi:10.1029/2011GL047660.

Signell, R. P., and W. R. Geyer (1991), Transient eddy Formation Around Headlands, J. Geophys. Res., 96(C2), 2561-2575, doi:10.1029/90JC02029.

Souza, J. M. A. C., C. de Boyer Montégut, and P. Y. Le Traon (2011), Comparison between three implementations of automatic identification algorithms for the quantification and characterization of mesoscale eddies in the South Atlantic Ocean, Ocean Sc., 7, 317-334, doi:10.5194/os-7-317-2011.

Tabata, S. (1982), The anticyclonic baroclinic eddy off Sitka, Alaska, in the northeast Pacific Ocean, J. Phys. Oceanogr., 12, 1260-1282, doi:10.1175/15200485(1982)012<1260:TABEOS>2.0.CO;2.

Tully, J. (1942), Surface non-tidal currents in the approaches to Juan de Fuca Strait, J. Fish. Res. Board Can., 5b(4), 398-409, doi:10.1139/f40-041. 
Vidal, V. M. V., F. V. Vidal, and J. M. Perez-Molero (1992), Collision of a Loop Current anticyclonic ring against the continental slope of the western Gulf of Mexico, J. Geophys. Res., 97(C2), 2155-2172, doi:10.1029/91JC00486.

Vukovich, F. M., and E. Waddel (1991), Interaction of a warm ring with the western slope in the Gulf of Mexico, J. Phys. Oceanogr., 21(7), 1062-1074.

Table 1. Start and end dates of the transects.

\begin{tabular}{|c|c|c|c|c|}
\hline \multirow{2}{*}{ Transect } & \multicolumn{2}{|c|}{ Start } & \multicolumn{2}{c|}{ End } \\
\cline { 2 - 5 } & Day & Hour (GMT) & Day & Hour (GMT) \\
\hline 1 & Aug. 25 & 01h38 & Aug. 25 & $04 \mathrm{~h} 48$ \\
\hline 2 & Aug. 25 & $18 \mathrm{~h} 27$ & Aug. 25 & $23 \mathrm{~h} 39$ \\
\hline 3 & Aug. 26 & $21 \mathrm{~h} 24$ & Aug. 27 & $01 \mathrm{~h} 16$ \\
\hline 4 & Aug. 27 & $21 \mathrm{~h} 31$ & Aug. 28 & $03 \mathrm{~h} 54$ \\
\hline
\end{tabular}

Table 2. Summary of the calculation of the position of the center of the eddy for each transect.

The along transect diameter at the depth given in column 2 is provided in column 3 .

\begin{tabular}{|c|c|c|c|c|c|}
\hline Transect & Depth (m) & Diameter $(\mathrm{km})$ & Single-depth transect center & Depth-averaged transect center & Transect-averaged eddy center \\
\hline \multirow{3}{*}{1} & -11 & 30 & $C 1 \_11: 3^{\circ} 33^{\prime} \mathrm{E}-42^{\circ} 33^{\prime} \mathrm{N}$ & \multirow{3}{*}{$\mathrm{C} 1: 3^{\circ} 34^{\prime} \mathrm{E}-42^{\circ} 33^{\prime} \mathrm{N}$} & \multirow{12}{*}{ C: $3^{\circ} 34^{\prime} \mathrm{E}-42^{\circ} 33^{\prime} \mathrm{N}$} \\
\hline & -15 & 33 & $C 1 \_15: 3^{\circ} 33^{\prime} \mathrm{E}-42^{\circ} 33^{\prime} \mathrm{N}$ & & \\
\hline & -19 & 35 & $C 1 \_19: 3^{\circ} 35^{\prime} \mathrm{E}-42^{\circ} 33^{\prime} \mathrm{N}$ & & \\
\hline \multirow{3}{*}{2} & -11 & 30 & C2_11: $3^{\circ} 35^{\prime} \mathrm{E}-42^{\circ} 30^{\prime} \mathrm{N}$ & \multirow{3}{*}{$\mathrm{C} 2: 3^{\circ} 34^{\prime} \mathrm{E}-42^{\circ} 31^{\prime} \mathrm{N}$} & \\
\hline & -15 & 29 & C2_15: $3^{\circ} 33^{\prime} \mathrm{E}-42^{\circ} 31^{\prime} \mathrm{N}$ & & \\
\hline & -19 & 28 & C2_19: $3^{\circ} 33^{\prime} \mathrm{E}-42^{\circ} 32^{\prime} \mathrm{N}$ & & \\
\hline \multirow{3}{*}{3} & -11 & 24 & C3_11: $3^{\circ} 35^{\prime} \mathrm{E}-42^{\circ} 30^{\prime} \mathrm{N}$ & \multirow{3}{*}{$\mathrm{C} 3: 3^{\circ} 36^{\prime} \mathrm{E}-42^{\circ} 32^{\prime} \mathrm{N}$} & \\
\hline & -15 & 24 & C3_15: $3^{\circ} 35^{\prime} \mathrm{E}-42^{\circ} 33^{\prime} \mathrm{N}$ & & \\
\hline & -19 & 26 & C3_19: $3^{\circ} 36^{\prime} \mathrm{E}-42^{\circ} 34^{\prime} \mathrm{N}$ & & \\
\hline \multirow{3}{*}{4} & -11 & 24 & C4-11: $3^{\circ} 33^{\prime} \mathrm{E}-42^{\circ} 33^{\prime} \mathrm{N}$ & \multirow{3}{*}{$\mathrm{C} 4: 3^{\circ} 35^{\prime} \mathrm{E}-42^{\circ} 34^{\prime} \mathrm{N}$} & \\
\hline & -15 & 22 & C4-15: $3^{\circ} 34^{\prime} \mathrm{E}-42^{\circ} 34^{\prime} \mathrm{N}$ & & \\
\hline & -19 & 16 & C4_-19: $3^{\circ} 37^{\prime} \mathrm{E}-42^{\circ} 34^{\prime} \mathrm{N}$ & & \\
\hline
\end{tabular}




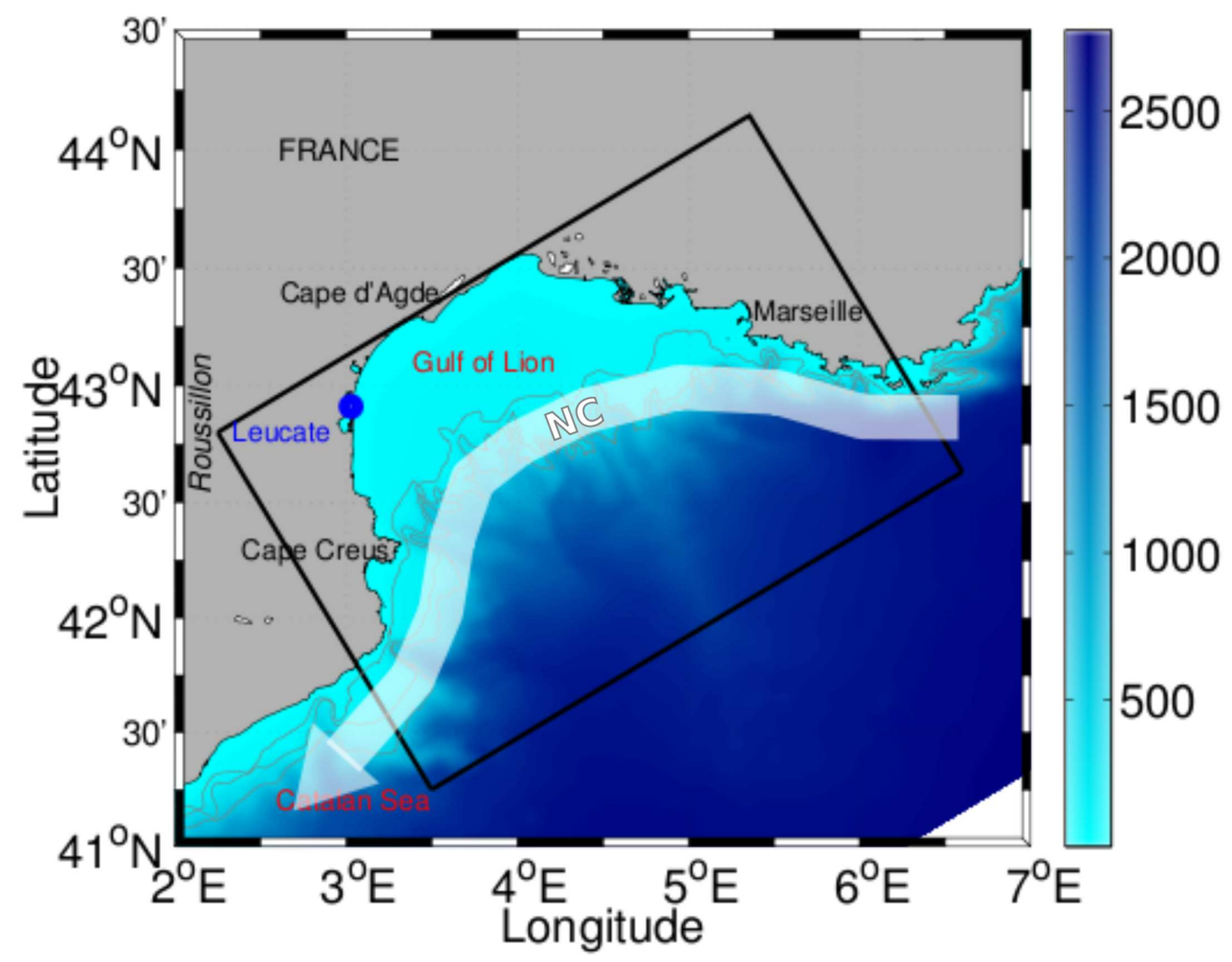

Figure 1. Model domain. The rectangle represents the model domain of $1 \mathrm{~km} \times 1 \mathrm{~km}$ resolution. Shaded color represents the bathymetry [m]. Isobaths at 100, 200 and $500 \mathrm{~m}$ are plotted with thin lines. The white arrow shows the mean position of the Northern Current (NC). 

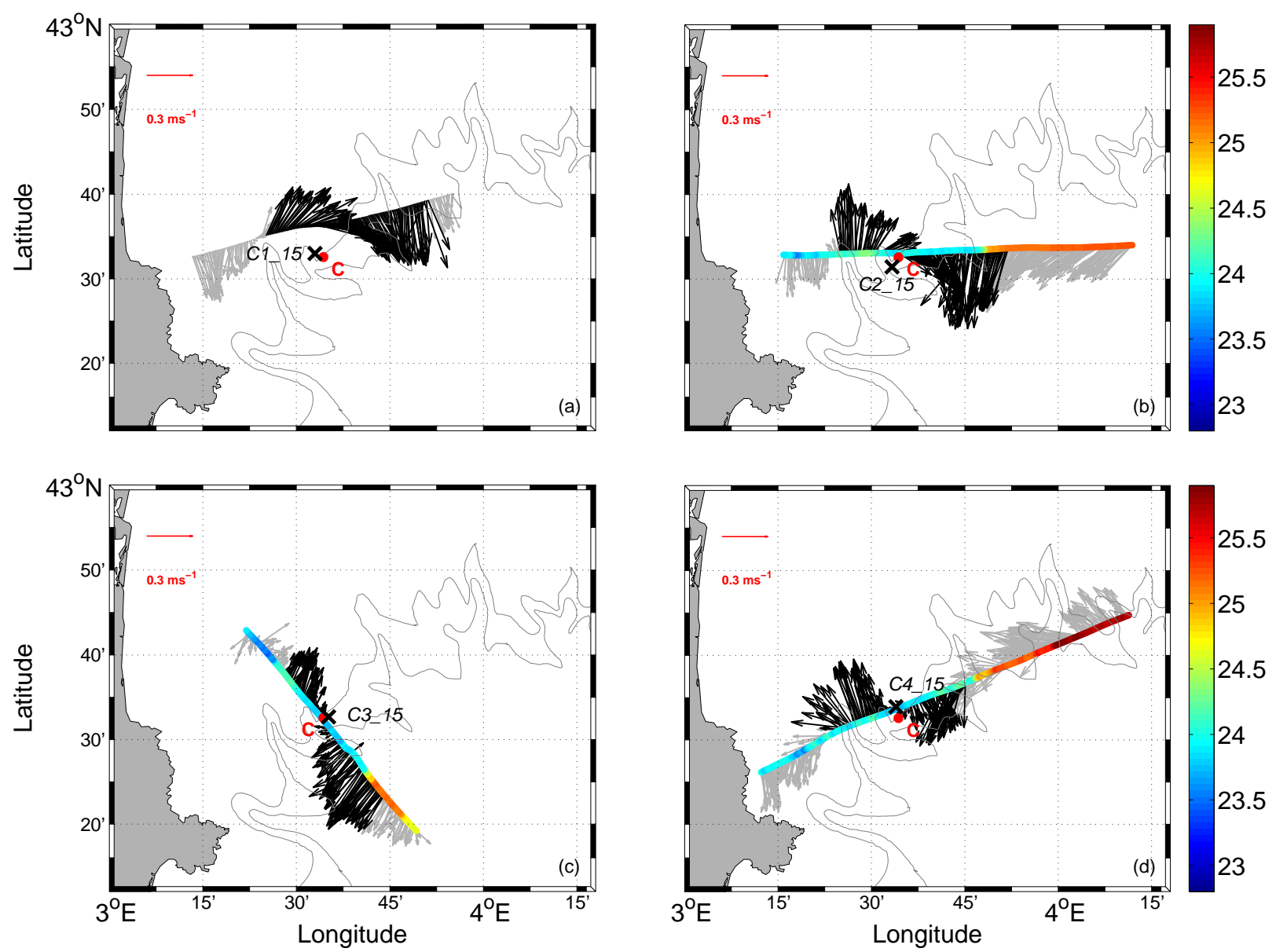

Figure 2. ADCP current vectors at $15 \mathrm{~m}$ depth for Transect 1 (a), Transect 2 (b), Transect 3 (c) and Transect 4 (d). The colors on the transect represent the surface temperature data $\left({ }^{\circ} \mathrm{C}\right)$ acquired along the trajectory. For each transect, the single-depth transect center at $15 \mathrm{~m}$ depth (black cross) is defined as the point for which the mean tangential velocity computed from the velocity vectors in black is maximum. The red dot corresponds to the eddy center. 

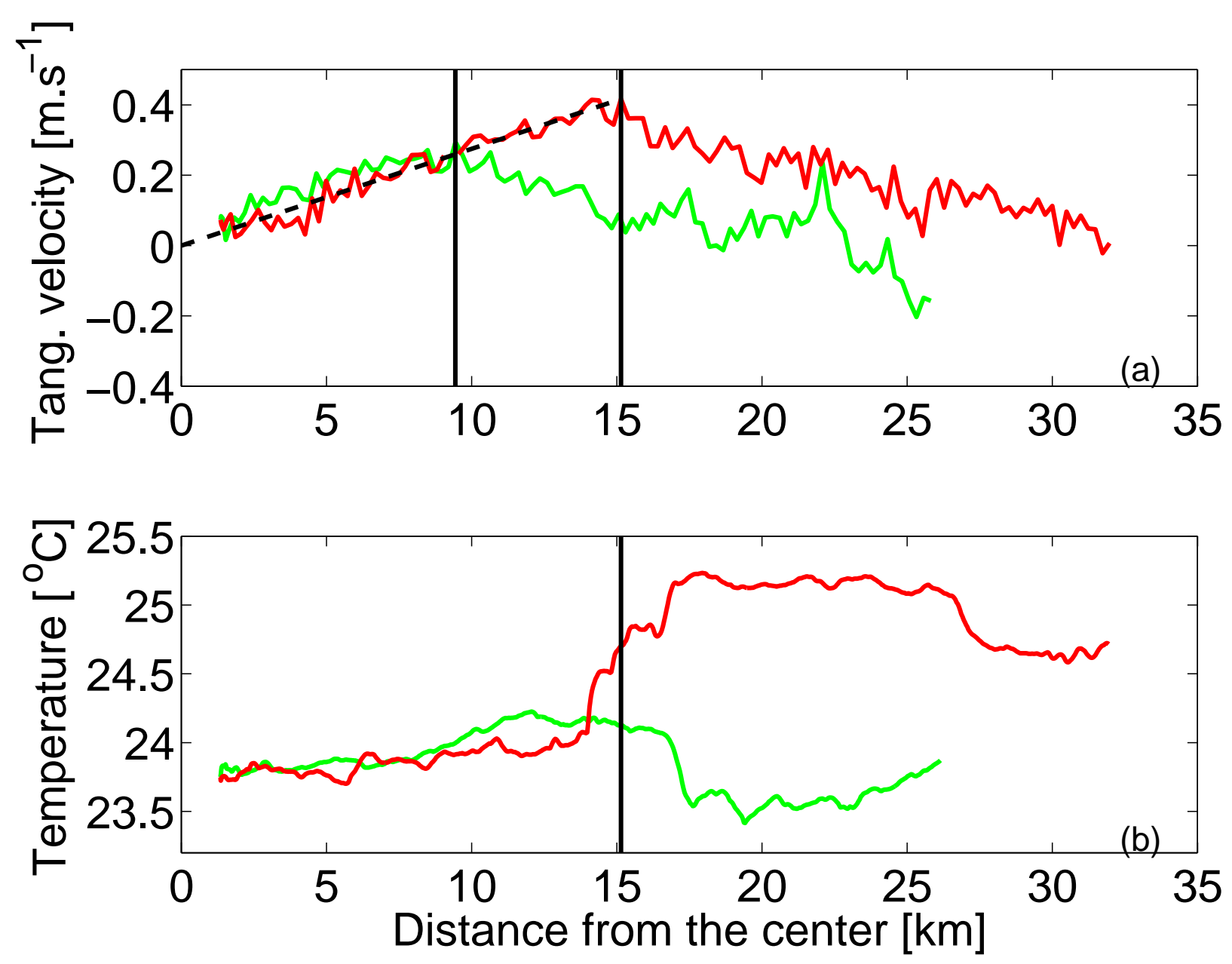

Figure 3. Distribution of tangential velocities at $15 \mathrm{~m}$ depth (a) and temperature at the surface (b) with respect to radial distance from C3_15. The green line corresponds to the data collected before crossing the center (hence northwest of the center C3_15 for Transect 3) and the red line corresponds to the data collected after the center (southeast of it). Black lines represent the distance from C3_15 where the maximum values of tangential velocities are reached. The black dashed line shows the linear increase of the tangential velocities in the case of a theoretical solid body rotation. 

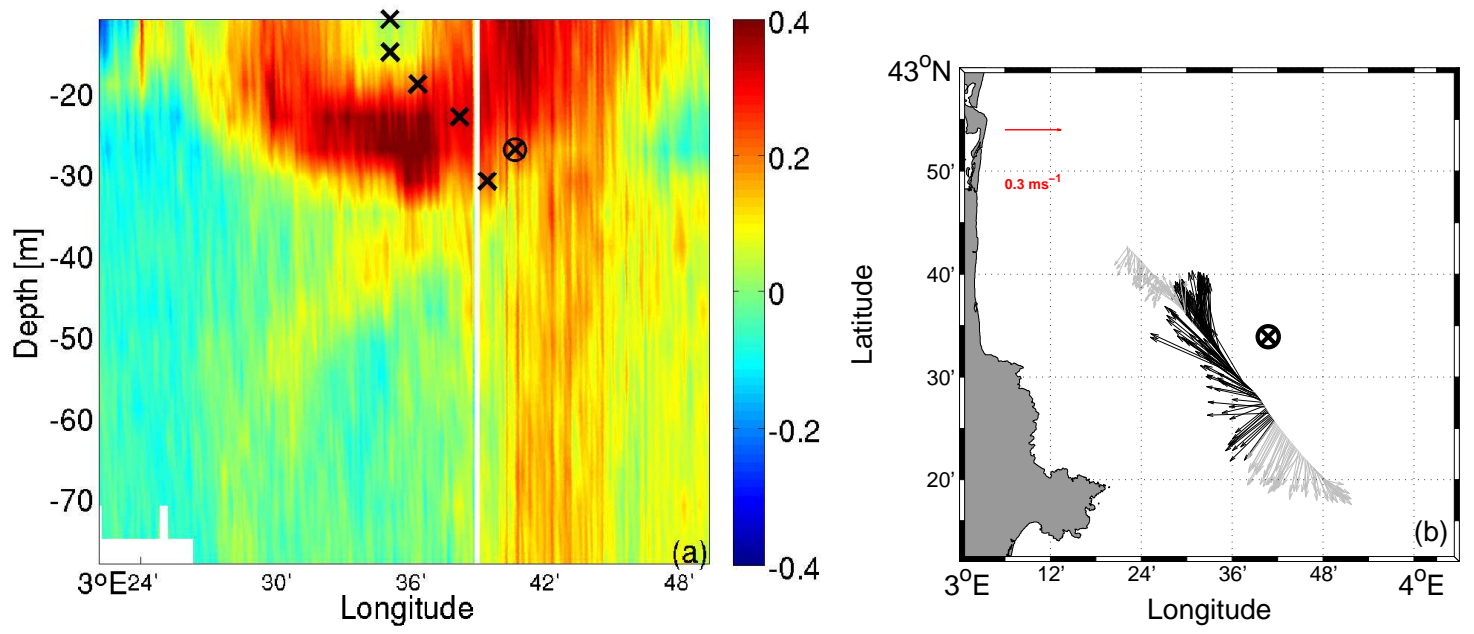

Figure 4. (a) Vertical section (depth versus longitude) of the tangential component (clockwise, positive) of the horizontal currents $\left[\mathrm{m} \mathrm{s}^{-1}\right]$ for Transect 3 . White pixels represent no data. ADCP current vectors at $27 \mathrm{~m}$ depth (b) for Transect 3 . The black cross represent the single-depth transect center. The black circle represents the single-depth transect center at $27 \mathrm{~m}$ depth, common to figures a and b. 

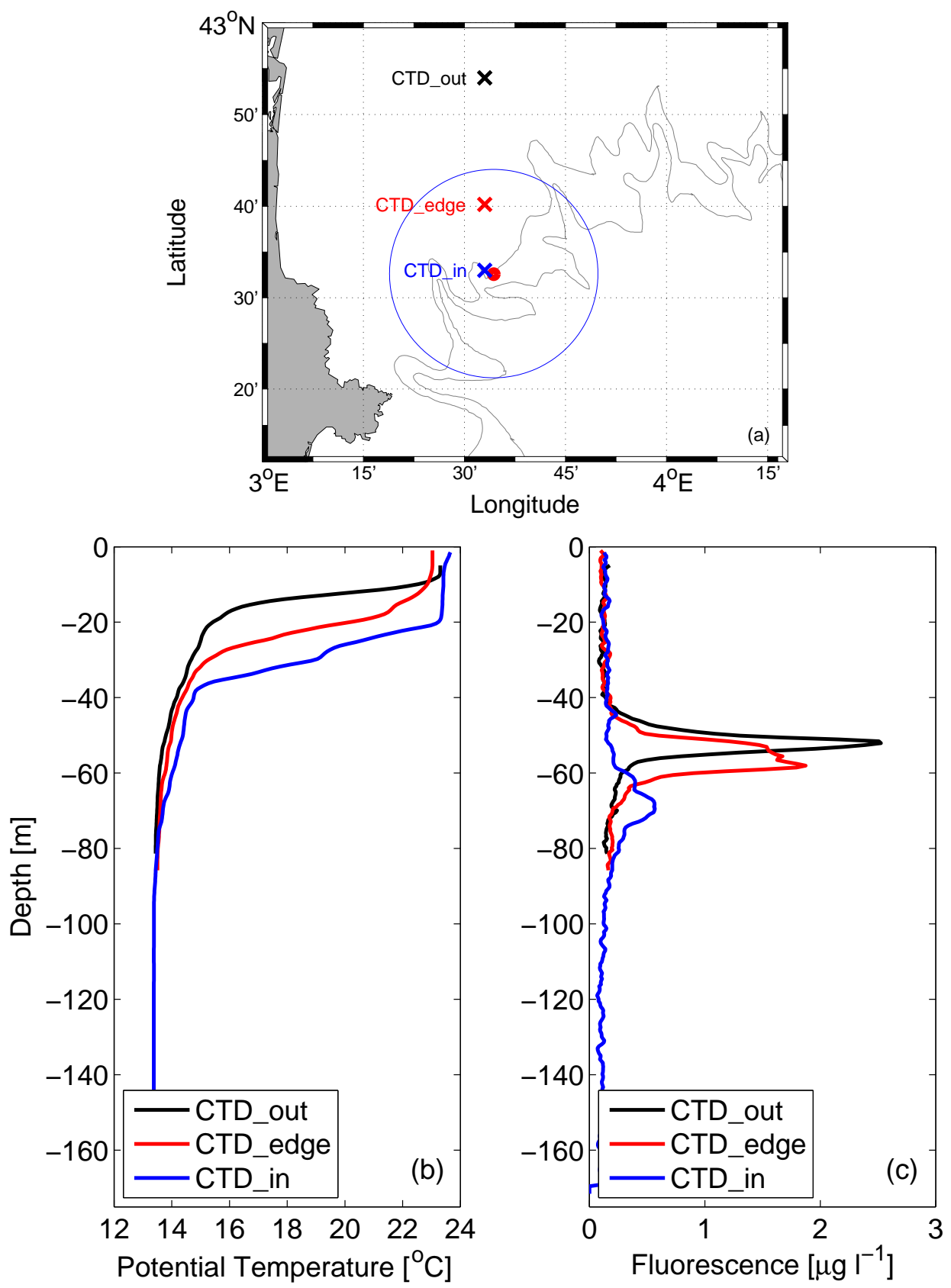

Figure 5. (a) The three crosses represent the positions of the CTD stations (CTD_in, CTD_edge, CTD_out). The blue circle is centered at the eddy center $\mathbf{C}$ (red dot) with a radius equal to the one estimated for the eddy. Vertical profiles of potential temperature (b) and fluorescence (c) at three CTD stations on August 26 (CTD_out: Outside part of the eddy located to the north; CTD_edge: Northern edge of the eddy; CTD_in: Inside part of the eddy). 


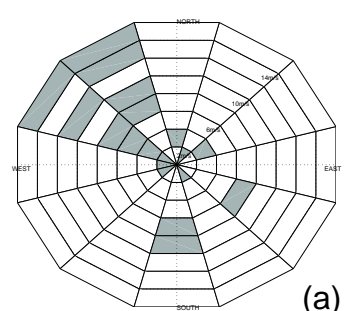

(a)

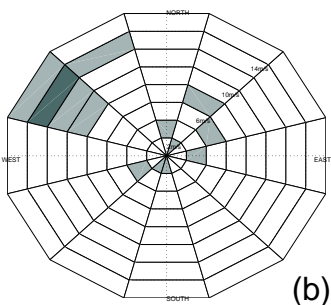

(b)

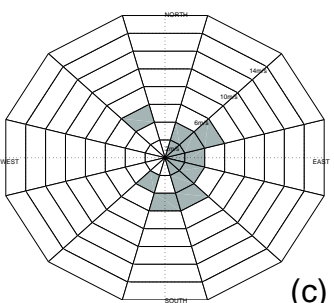

(c)
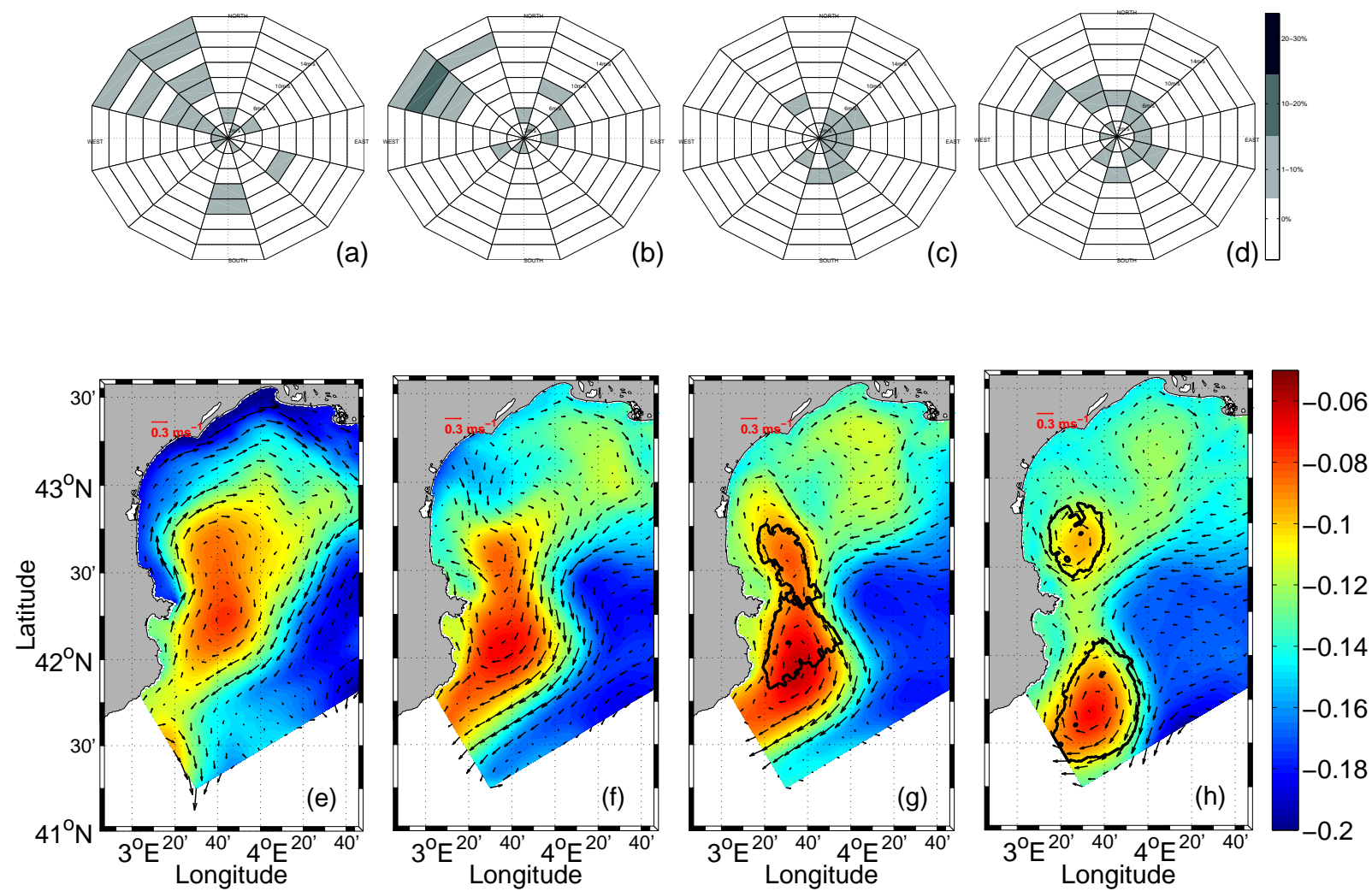

Figure 6. Time sequence of the generation process of A2-Latex09 in 2009. Top: wind rose representation (intensity and frequency) at station Leucate on (a) 2009/07/18 to 20; (b) 2009/08/06 to 08; (c) 2009/08/14 to 16; (d) 2009/08/25 to 27; colors representing wind frequency (\%). Bottom: sea surface height [m] and current velocity field at $5 \mathrm{~m}$ depth on (e) 2009/07/20; (f) 2009/08/08; (g) 2009/08/16; (h) 2009/08/27. Black contours in (g) and (h) show the eddies identification issued from the wavelet analysis. 


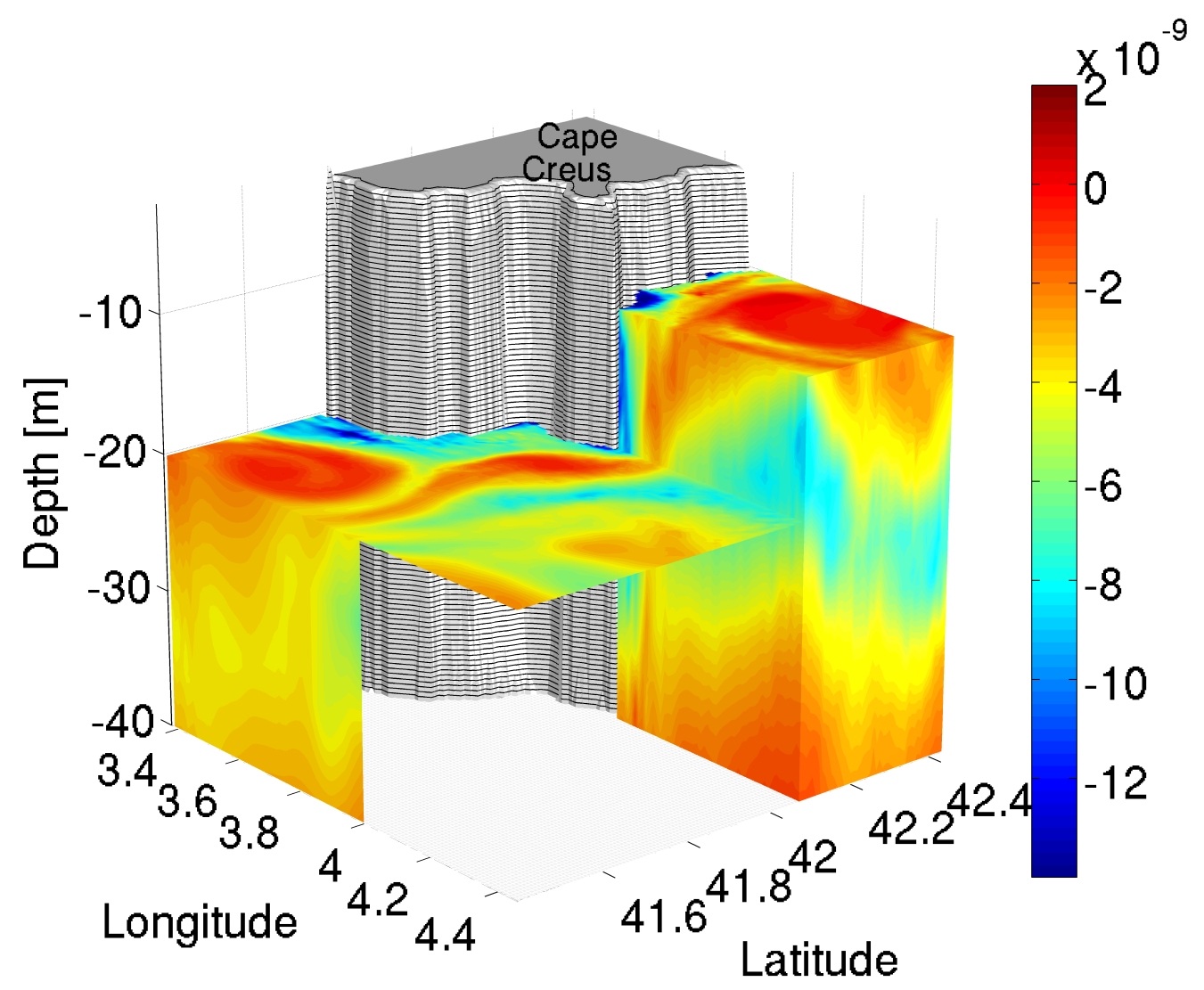

Figure 7. 3-dimensional sections of potential vorticity $\left[\mathrm{kg} \mathrm{m}^{-4} \mathrm{~s}^{-1}\right]$ in color on September 3 . The coast is represented in gray with the position of the Cape Creus. At $10 \mathrm{~m}$ depth, in the first section, we can distinguish the presence of A2-Latex09 upstream the Cape Creus. In the lee of the Cape, the transient structure is evidenced at $20 \mathrm{~m}$ depth. The Catalan eddy is also visualized farther off the coast and until $40 \mathrm{~m}$ depth. 

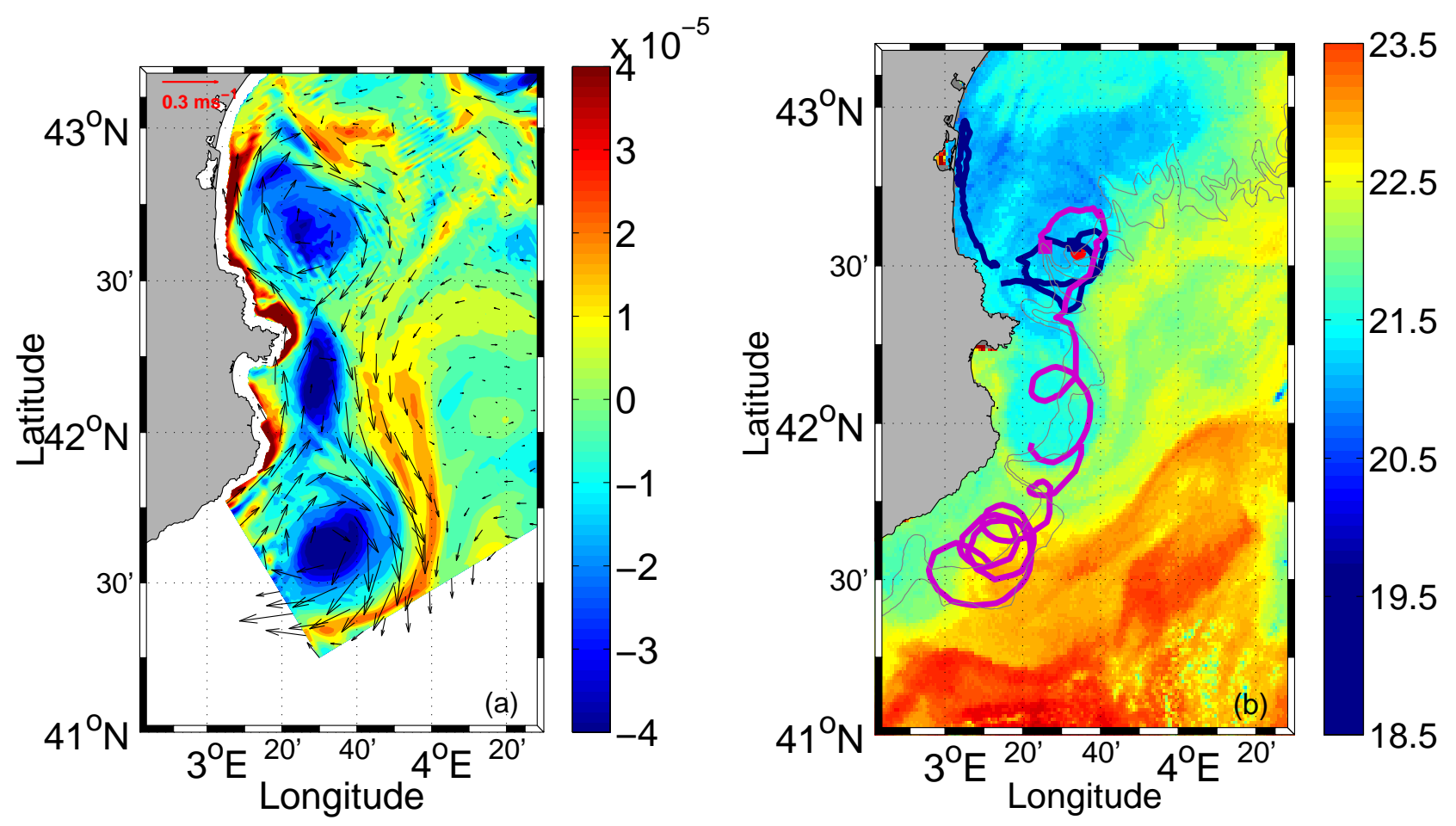

Figure 8. (a) Modeled relative vorticity $\left[\mathrm{s}^{-1}\right]$ and current velocity field at $20 \mathrm{~m}$ depth on September 3. (b) $S S T_{b}$ satellite image on August 28 (data from Météo-France) and drifter trajectories (drifter No. 83631 in blue - drifter No. 83632 in purple) from August 26 to September 12. The squares represent the drifters' initial positions. The red dot corresponds to the eddy center. 